\title{
SISTEM PENDUKUNG KEPUTUSAN PEMBERIAN BONUS KARYAWAN MENGGUNAKAN METODE FUZZY LOGIC (STUDI KASUS: PT. JAYA RAYA)
}

\author{
Ridho Taufiq S. ${ }^{1}$, Petrus Sokibi ${ }^{2}$, Rommy Rifaldi Hartoyo ${ }^{3}$ \\ Sekolah Tinggi Manajemen Informatika dan Komputer CIC Cirebon \\ Jln. Kesambi 202, Kota Cirebon, Jawa Barat. Telp.(0231) 220250 \\ e-mail: ridho.taufiq@cic.ac.id ${ }^{1}$, petrus.sokibi@cic.ac.id ${ }^{2}$, rommyrifaldi@yahoo.com ${ }^{3}$
}

\begin{abstract}
Pemberian bonus pada karyawan merupakan suatu bentuk apresiasi perusahaan kepada karyawan yang ada pada PT Jaya Raya. PT Jaya Raya merupakan perusahaan terasi yang terdapat di Cirebon. Hal ini bertujuan untuk meningkatkan kinerja karyawan dan menjadi motivasi untuk karyawan. Pemberian bonus karyawan yang selama ini berjalan tidak memiliki besaran bonus yang pasti untuk setiap karyawan sehingga perusahaan kesulitan dalam menentukan besaran anggaran bulanan. Untuk itu diperlukan sebuah sistem yang dapat menentukan besaran bonus karyawan. Sistem pendukung keputusan penentuan besaran bonus merupakan sebuah sistem yang dapat membantu bagian Keuangan dalam menentukan besaran bonus serta mempermudah dalam pembuatan laporan bulanan. Sistem ini menggunakan metode Fuzzy logic model tahani yang merupakan metode query data yang mengubah data tidak pasti menjadi pasti, sistem ini terdapat empat indikator yang digunakan yaitu absensi, sikap kerja, masa kerja, dan jumlah produksi. Data data pada indikator akan diolah untuk mendapat besaran bonus setiap karyawan. Untuk membangun sistem aplikasi sistem pendukung keputusan ini, dalam perancangan menggunakan Ms Visio, bahasa pemograman PHP dengan menggunakan Notepad++ sebagai text editor serta menggunakan basis data MySQL dengan perangkat lunak Xampp.Hasil dari penelitian ini adalah Aplikasi Sistem Pendukung Keputusan Penentuan Besaran Bonus Karyawan dengan menggunakan metode Fuzzy Logic model Tahani yang dapat mempermudah bagian keuangan dalam menentukan besaran bonus.
\end{abstract}

Kata Kunci : Sistem Pendukung Keputusan, Fuzzy Logic, Bonus, Karyawan

\begin{abstract}
Abstrak
Giving bonuses to employees is a form of corporate appreciation to employees at PT Jaya Raya. PT Jaya Raya is a shrimp paste company in Cirebon. It aims to improve employee performance and become a motivation for employees. Providing employee bonuses that have been running for this time do not have a party bonus amount for each employee so the company has difficulty in determining the amount of the monthly budget. For that we need a system that can determine the amount of employee bonus.Decision support system to determine the amount of bonus is a system that can help the Finance department in determining the amount of bonuses and facilitate the making of monthly reports. This system uses the Tahani Fuzzy logic model method which is a data query method that changes uncertain data to be certain, this system has four indicators that are used, namely attendance, work attitude, years of service, and total production. Data on the indicator will be processed to get the bonus amount of each employee. To build this decision support system application system, in designing using Ms Visio, the PHP programming language using Notepad ++ as a text editor and using the MySQL database with Xampp software.The results of this study are the Application of Supporting System Decision for the Determination of Employee Bonus Amount by using the Tahani Fuzzy Logic model which can simplify the financial part in determining the bonus amount.
\end{abstract}

Keywords: Decision Support Systems, Fuzzy Logic, Bonuses, Employees 


\section{Pendahuluan}

Pemberian bonus merupakan suatu bentuk apresiasi suatu perusahaan terhadap kinerja karyawan, besarnya apresiasi suatu perusahaan dapat dilihat dengan besarnya nilai yang diberikan perusahaan kepada karyawan yang sudah bekerja lama. Saat ini banyak perusahaan yang kurang menghargai kinerja karyawannya dengan alasan dapat mengganggu pendapatan perusahaan dan dapat merusak keuangan perusahaan. Namun pemberian bonus juga sebenarnya dapat meningkatnya kinerja karyawan dan dapat menjadi suatu motivasi tersendiri untuk setiap karyawan, pemberian bonus sudah menjadi suatu kewajiban perusahaan yang harus dibayarkan kepada karyawan.

PT. Jaya Raya merupakan perusahaan non-ekspor yang memproduksi terasi dan garam dimana jumlah produksi perhari cukup tinggi. Perusahaan ini terletak di Jalan Raya Cirebon-Tegal KM 8,8. PT. Jaya Raya telah menerapkan pemberian bonus kepada karyawan yang diberikan setiap akhir tahun berdasarkan perhitungan setiap bulan sebagai bentuk apresiasi perusahaan namun belum memiliki sistem pemberian bonus berdasarkan parameter yang jelas sehingga dibutuhkan waktu dalam penentuan karyawan yang berhak mendapatkan bonus. Selain itu, penentuan bonus yang dilakukan belum memiliki besaran yang pasti untuk setiap karyawan yang berhak menerimanya sehingga Bagian Keuangan mengalami kesulitan dalam menentukan besaran anggaran bulanan perusahaan yang tentunya berdasarkan kemampuan perusahaan dalam memberikan besaran bonus karyawan.

Metode Fuzzy Logic merupakan peningkatan dari logika Boolean yang berhadapan dengan konsep kebenaran sebagian dimana data yang digunakan kurang lengkap mengandung ketidakpastian dan ambigu yang diubah menjadi suatu data yang sudah diklasifikasikan. Keunggulan dari metode ini adalah menggubah data yang tidak pasti menjadi data yang diklarifikasikan dan dipetakan berdasarkan penentuan besaran bonus.

Berdasarkan uraian dan penjelasan diatas maka salah satu solusi untuk menyelesaikan masalah tersebut, penulis tertarik untuk membangun aplikasi berbasis komputer dalam penelitian ini dengan judul Sistem Pendukung Keputusan Pemberian Bonus Karyawan dengan pembobotan kriteria menggunakan metode Fuzzy Logic model Tahani yang didalamnya terdapat empat kriteria yaitu jumlah produksi, absensi, sikap kerja dan masa kerja.

\section{Landasan Teori}

\subsection{Sistem Pendukung Keputusan}

Menurut Turban (2005), Sistem Pendukung Keputusan (SPK) atau Decision Support System (DSS) adalah sebuah sistem yang mampu memberikan kemampuan pemecahan masalah maupun kemampuan pengkomunikasian untuk masalah dengan kondisi semi-terstruktur dan tidak terstruktur. Sistem ini digunakan untuk membantu pengambilan keputusan dalam situasi semi-terstruktur dan situasi yang tidak terstruktur, dimana tak seorangpun tahu secara pasti bagaimana keputusan seharusnya dibuat.

SPK bertujuan untuk menyediakan informasi, membimbing, memberikan prediksi serta mengarahkan kepada pengguna informasi agar dapat melakukan pengambilan keputusan dengan lebih baik. Dapat juga dikatakan sebagai sistem komputer yang mengolah data menjadi informasi untuk mengambil keputusan dari masalah semi-terstruktur yang spesifik.

Tahapan dari Sistem Pendukung Keputusan adalah sebagai berikut.

1. Mendefinisikan masalah,

2. Pengumpulan data atau elemen informasi yang relevan,

3. Pengolahan data menjadi informasi, baik dalam bentuk laporan grafik maupun tulisan, serta menentukan alternatif-alternatif solusi (bisa dalam persentase).

Tujuan dari Sistem Pendukung Keputusan adalah sebagai berikut.

1. Mendukung dalam pengambilan keputusan suatu masalah,

2. Meningkatkan efektifitas, bukan efisiensi, dalam pengambilan keputusan. Dalam pemrosesannya, SPK dapat menggunakan bantuan dari sistem lain seperti Artificial Intelligence, Expert Systems, Fuzzy Logic Method, AHP Method, dll. 


\subsection{Fuzzy Logic}

Basis data (database) merupakan kumpulan dari data yang saling berhubungan satu dengan yang lainnya, tersimpan di perangkat keras komputer dan digunakan perangkat lunak untuk memanipulasinya. Sistem basis data (database system) adalah suatu sistem informasi yang mengintegrasikan kumpulan data yang saling berhubungan satu dengan yang lainnya dan membuatnya tersedia untuk beberapa aplikasi dalam suatu organisasi.

Basis data yang umumnya kita gunakan, memiliki data yang lengkap dalam setiap tabelnya. Demikian pula, apabila hendak dibuat suatu query, maka query itupun harus menggunakan data yang ada pada tabel dan kata-kata kunci yang berlaku di SQL. Apabila kita memiliki data yang kurang lengkap, mengandung ketidakpastian dan ambigu, maka penggunaan basis data biasa menjadi sulit untuk dilakukan. Dari sinilah, kita dapat memanfaatkan logika fuzzy untuk mengantisipasi pemanipulasian data dalam basis data yang mengandung ketidakpastian, baik dari sisi data maupun query-nya. (Sri dan Hari, 2010).

\subsection{Basis Data Fuzzy Model Tahani}

Basis data yang umumnya digunakan memiliki data yang lengkap dalam setiap tabelnya. Ketika membuat suatu query, maka query harus menggunakan data yang ada pada tabel dan kata kunci yang berlaku di SQL. Apabila data yang dimiliki kurang lengkap, mengandung ketidakpastian dan ambigu, maka penggunaan basis data biasa menjadi sulit digunakan. Data yang mengandung ketidakpastian yaitu nilai yang belum diklasifikasikan, berikut kategori jam kerja ke dalam himpunan: PENDEK, SEDANG, dan PANJANG dalam bentuk fungsi keanggotaan.

Apabila data yang dimiliki bersifat tidak pasti dan ambigu, maka kita bisa mengatasinya dengan menggunakan basis data fuzzy. Selama ini, sudah ada beberapa penelitian tentang basis data fuzzy. Salah satu diantaranya adalah model Tahani. Basis data fuzzy model Tahani masih tetap menggunakan relasi standar, hanya saja model ini menggunakan teori himpunan fuzzy untuk mendapatkan informasi pada query-nya. (Sri dan Hari, 2010).

\section{$2.4 \quad$ Fungsi Keanggotaan}

Fungsi keanggotaan (membership function) adalah suatu kurva yang menunjukkan pemetaan titiktitik input data ke dalam nilai keanggotaanya (sering disebut juga dengan derajat keanggotaan) yang memiliki interval antara 0 sampai 1. Salah satu cara yang dapat digunakan untuk mendapatkan nilai keanggotaan adalah dengan pendekatan fungsi. Berdasarakan (Sri dan Hari, 2010), ada beberapa fungsi yang bisa digunakan :

1. Representasi Kurva Linear

Pada representasi linear, pemetaan input derajat keanggotaannya digambarkan sebagai suatu garis lurus. Bentuk ini paling sederhana dan menjadi pilihan yang baik untuk mendekati suatu konsep yang kurang jelas. Ada 2 keadaan himpunan fuzzy yang linear. Pertama, kenaikan himpunan dimulai pada nilai domain yang memiliki derajat keanggotaan nol (0) bergerak ke kanan menuju ke nilai domain yang memiliki derajat keanggotaan lebih tinggi serperti terlihat pada Gambar 2.1.

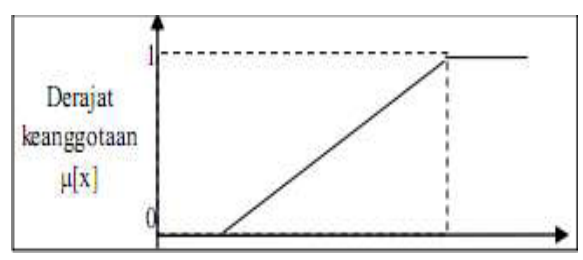

Gambar 1. Representasi Linear Naik (Sumber: Sri Kusumadewi, Aplikasi Logika Fuzzy untuk Pendukung Keputusan,2010) 
Fungsi Keanggotaan :

$$
\mu[x]\left\{\begin{array}{clc}
0 & \rightarrow & x \leq a \\
(x-a) /(b-a) & \rightarrow & (a \leq x \leq b) \\
1 & \rightarrow & x \geq b
\end{array}\right.
$$

Pada representasi linear turun, garis lurus dimulai dari nilai domain dengan derajat keanggotaan tertinggi pada sisi kiri, kemudian bergerak menurun ke nilai domain yang memiliki derajat keanggotaan lebih rendah yang dibuat pada Gambar 2.2.

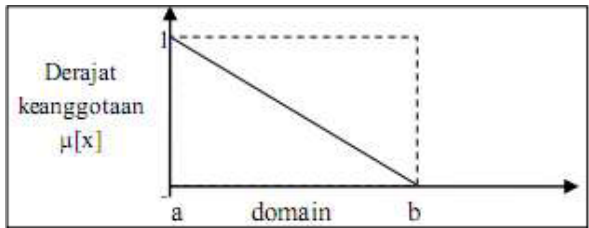

Gambar 2. Representasi Linear Turun (Sumber: Sri Kusumadewi, Aplikasi Logika Fuzzy untuk Pendukung Keputusan,2010)

Fungsi Keanggotaan:

$$
\mu[x]=\left\{\begin{array}{cc}
0 & \rightarrow x \geq a \\
(b-x) /(b-a) & \rightarrow(a \leq x \leq b)
\end{array}\right.
$$

2. Representasi Kurva Segitiga

Kurva Segitiga pada dasarnya merupakan gabungan antara 2 garis (linear) seperti terlihat pada Gambar 2.3.

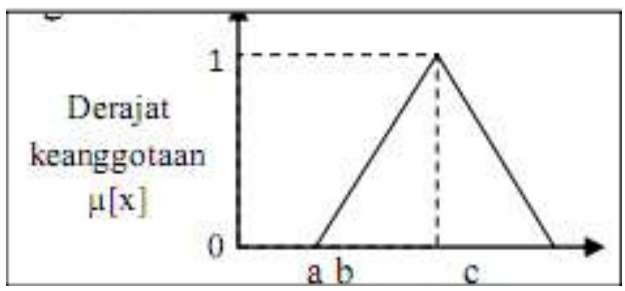

Gambar 3. Kurva Segitiga (Sumber: Sri Kusumadewi, Aplikasi Logika Fuzzy untuk Pendukung Keputusan,2010)

Fungsi Keanggotaan:

$$
\mu[x]=\left\{\begin{array}{ccc}
0 & \rightarrow & x \leq a \text { atau } x \geq c \\
(x-a) /(b-a) & \rightarrow & (a \leq x \leq b) \\
(c-x) /(c-b) & \rightarrow & b \leq x \leq c
\end{array}\right.
$$

3. Representasi Kurva Bentuk Bahu

Daerah yang terletak di tengah-tengah suatu variabel yang direpresentasikan dalam bentuk segitiga, pada sisi kanan dan kirinya akan naik dan turun (misalkan: Dingin bergerak ke Sejuk bergerak ke Hangat dan bergerak ke Panas). Tetapi terkadang salah satu sisi dari variabel tersebut tidak mengalami perubahan. Sebagai contoh, apabila telah mencapai kondisi Panas, kenaikan temperatur akan tetap berada pada kondisi Panas. Himpunan fuzzy " bahue, bukan Segitiga, digunakan untuk mengakhiri variabel suatu daerah fuzzy. Bahu kiri bergerak dari benar ke salah, bahu kanan bergerak bergerak dari salah ke benar. Seperti pada Gambar 2.4 : 


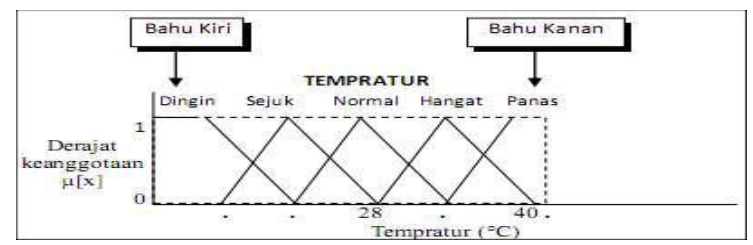

Gambar 4. Representasi Kurva Bahu pada Variabel Temperatur (Sumber:Sri Kusumadewi, Aplikasi Logika Fuzzy untuk Pendukung Keputusan,2010)

\section{Analisa dan Perancangan Sistem}

\subsection{Analisis Sistem}

pemberian bonus pada PT Jaya Raya dipengaruhi oleh beberapa faktor. Faktor-faktor yang menjadi bahan penilaian antara lain :

1. Jumlah produksi (Rendah, Sedang dan Tinggi)

2. Absensi (Rendah, Sedang dan Tinggi)

3. Sikap kerja (Kurang, Cukup dan Baik)

4. Masa kerja (Baru dan Senior)

Penentuan jenis variabel didapat berdasarkan hasil pengumpulan data yang telah penulis lakukan. Fungsi keanggotaan yang digunakan ada tiga jenis, yaitu linear turun, segitiga, dan linear naik. Adapun jenis variabel dan himpunan Fuzzy dapat dilihat pada tabel dibawah ini :

Tabel 1. Variabel Fuzzy

\begin{tabular}{|c|l|l|c|c|}
\hline Variabel & Himpunan Fuzzy & Fungsi Keanggotaan & Domain & Persentase \\
\hline \multirow{3}{*}{ Jumlah Produksi } & Rendah & Linear Turun & $0-300-400$ & $0 \%$ \\
\cline { 2 - 5 } & Sedang & Segitiga & $300-400-500$ & $5 \%$ \\
\cline { 2 - 5 } & Tinggi & Linear Naik & $400-500$ & $10 \%$ \\
\hline \multirow{3}{*}{ Absensi } & Rendah & Linear Turun & $0-22-24$ & $0 \%$ \\
\cline { 2 - 5 } & Sedang & Segitiga & $22-24-26$ & $5 \%$ \\
\cline { 2 - 5 } & Tinggi & Linear Naik & $24-26$ & $10 \%$ \\
\hline \multirow{3}{*}{ Masa Kerja Kerja } & Kurang & Linear Turun & $0-60-75$ & $0 \%$ \\
\cline { 2 - 5 } & Cukup & Segitiga & $60-75-90$ & $5 \%$ \\
\cline { 2 - 5 } & Baik & Linear Naik & $75-90$ & $10 \%$ \\
\cline { 2 - 5 } & Baru & Linear turun & $0-1-5$ & $0 \%$ \\
\cline { 2 - 5 } & Senior & Linear Naik & $1-5$ & $10 \%$ \\
\hline
\end{tabular}

Adapun penjelasan mengenai tabel 1 sebagai berikut:

1. Variabel Jumlah Produksi

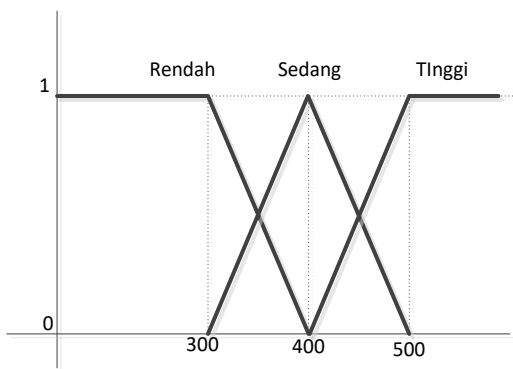

Gambar 5. Fungsi Keanggotaan Variabel Jumlah Produksi

Fungsi keanggotaan Jumlah Produksi dapat dirumuskan pada persamaan (4), (5), dan (6)sebagai berikut : 


\begin{tabular}{|c|c|c|}
\hline & $\begin{array}{c}1 \\
400-X \\
\end{array}$ & $\begin{array}{l}; x \leq 300 \\
\cdot 300<x<400\end{array}$ \\
\hline$\mu$ Jumlan Produks1 Rendah $[\mathrm{X}]=$ & $0^{100}$ & $\begin{array}{l}; 300 \leq x \leq 400 \\
; x>400\end{array}$ \\
\hline
\end{tabular}

\begin{tabular}{|c|c|c|}
\hline$\mu$ Jumlah Produksi $\operatorname{Sedang}[\mathrm{X}]=$ & $\begin{array}{c}\frac{0}{x-700} \\
\frac{500-x}{100} \\
100\end{array}$ & $\begin{array}{l}; x \leq 300 \text { atau } x \geq 500 \\
; 300 \leq x \leq 400 \\
; 400 \leq x \leq 500\end{array}$ \\
\hline$\mu$ Jumlah Produksi Tinggi $[\mathrm{X}]=$ & $\begin{array}{c}0 \\
\frac{x-400}{100} \\
1\end{array}$ & $\begin{array}{l}; x \leq 400 \\
; 400 \leq x \leq 500 \\
; x \geq 500\end{array}$ \\
\hline
\end{tabular}

2. Variabel Absensi

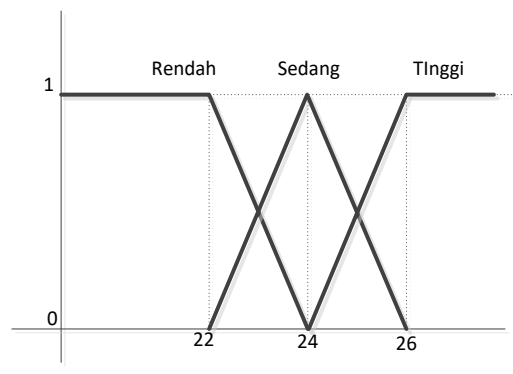

\section{Gambar 6. Fungsi Keanggotaan Variabel Absensi}

Fungsi keanggotaan Absensi dapat dirumuskan pada persamaan (7), (8), dan (9) sebagai berikut :

$\mu$ Absensi $\operatorname{Rendah[}[\mathrm{X}]=\quad \begin{array}{ll}1 & ; \mathrm{x} \leq 22 \\ \frac{24-x}{2} & ; 22 \leq \mathrm{x} \leq 24 \\ 0 & ; \mathrm{x} \geq 24\end{array}$
.....(7)

\begin{tabular}{|c|c|c|c|}
\hline \multirow[t]{2}{*}{$\mu$ Absensi Sedang $[\mathrm{X}]=$} & \multirow{2}{*}{$\begin{array}{l}0 \\
\frac{x-22}{2} \\
\frac{26-x}{2}\end{array}$} & \multicolumn{2}{|c|}{$\begin{array}{l}; x \leq 22 \text { atau } x \geq 24 \\
; 22 \leq x \leq 24\end{array}$} \\
\hline & & $; 24 \leq x \leq 26$ & .....(8) \\
\hline \multirow{3}{*}{$\mu$ Absensi Tinggi $[X]=$} & 0 & $; x \leq 24$ & \\
\hline & $\frac{x-24}{2}$ & $; 24 \leq x \leq 26$ & \\
\hline & 1 & $; x \geq 26$ & .(9) \\
\hline
\end{tabular}


3. Variabel Sikap Kerja

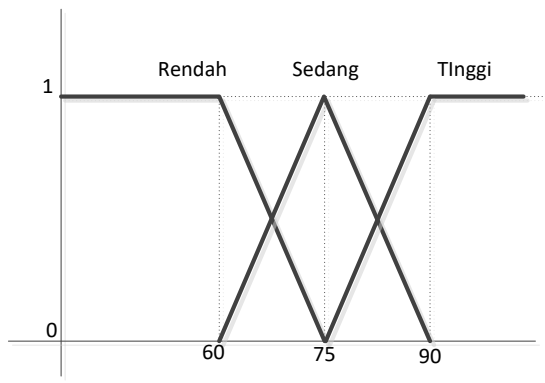

\section{Gambar 7. Fungsi Keanggotaan Variabel Sikap Kerja}

Fungsi keanggotaan sikap kerja dapat dirumuskan pada persamaan (10),(11), dan (12) sebagai berikut :

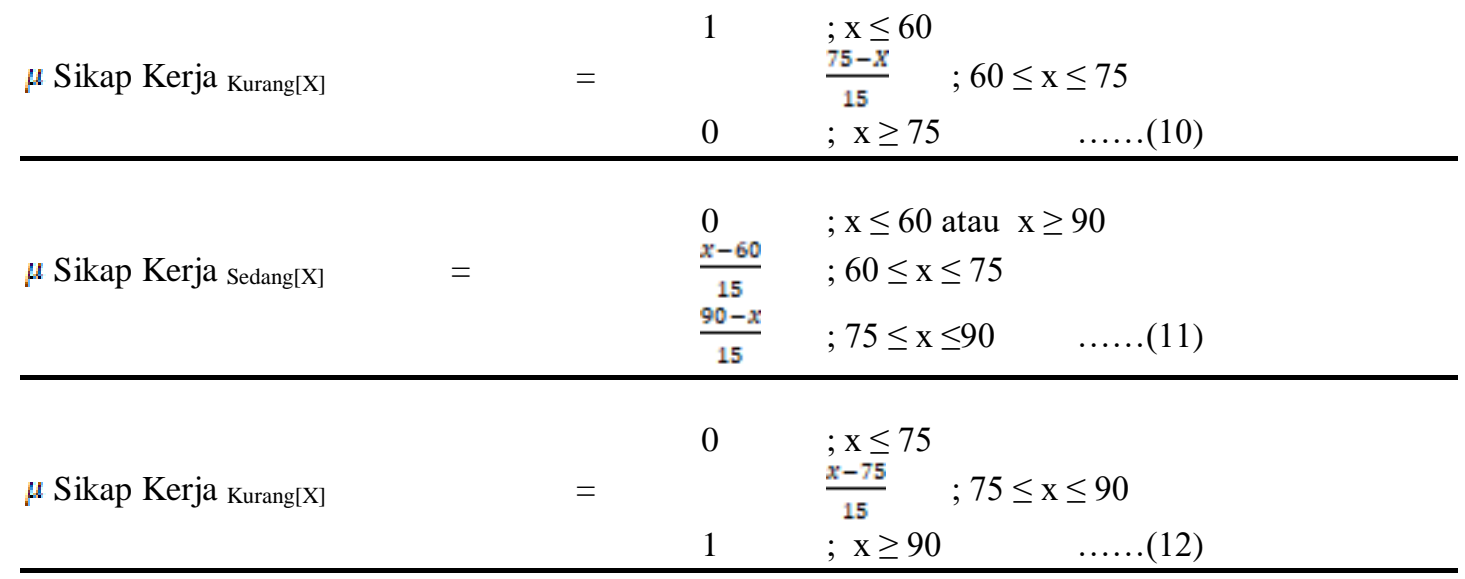

4. Variabel Masa Kerja

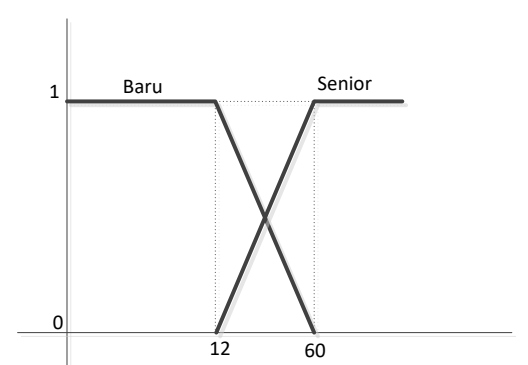

Gambar 8. Fungsi Keanggotaan Variabel Masa Kerja

Fungsi keanggotaan Masa Kerja dapat dirumuskan pada persamaan (13), dan (14) sebagai berikut :

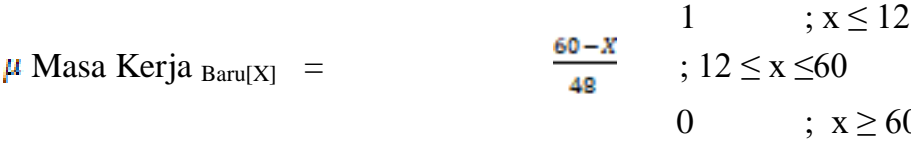

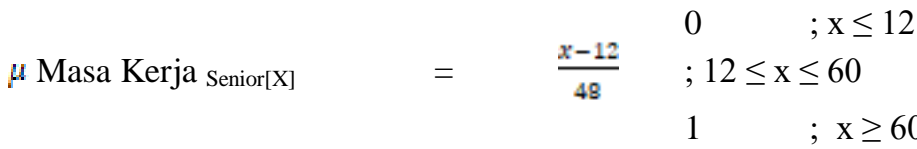

.....(14)


Persentase diperoleh berdasarkan rumus :

1. Persentase $[\mathrm{x}]=0 \% \rightarrow(x \leq a)$

2. Persentase $[\mathrm{x}]=10 \% \rightarrow(c \leq x)$

3. Persentase $[\mathrm{x}]=((x-a)) /((b-a)) * 5 \% \rightarrow(a \leq x \leq b)$

4. Persentase $[\mathrm{x}]=5+(((x-b)) /((c-b)) * 5 \%) \rightarrow(b \leq x \leq c)$

Keterangan:

$x=$ nilai suatu variabel

$a=$ nilai batas bawah suatu variabel

$b=$ nilai batas tengah suatu variabel

$c=$ nilai batas atas suatu variabel

\subsection{Use-Case Diagram}

Use-Case Diagram adalah diagram yang menggambarkan aktor, use-case dan relasinya sebagai suatu urutan tindakan yang memberikan nilai yang terukur untuk aktor. Aktor yang terlibat didalam usecase diagram yang akan dibuat adalah :

1. Bagian keuangan

2. Human Resource Development

3. Direktur

Berikut ini adalah gambar use-case diagram yang diusulkan pada sistem pendukung keputusan pemberian bonus karyawan di PT. Jaya Raya dengan metode fuzzy logic :

A. Use-Case Diagram Human Resource Development(HRD)

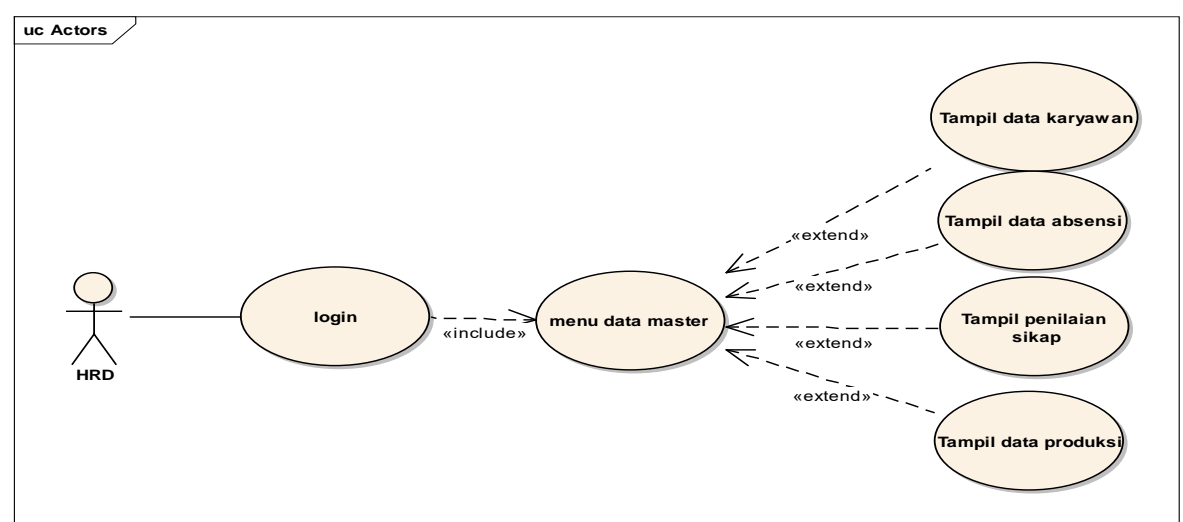

Gambar 9.Use-Case Diagram Human Resource Development (HRD)

B. Use-Case Diagram Bagian Keuangan 


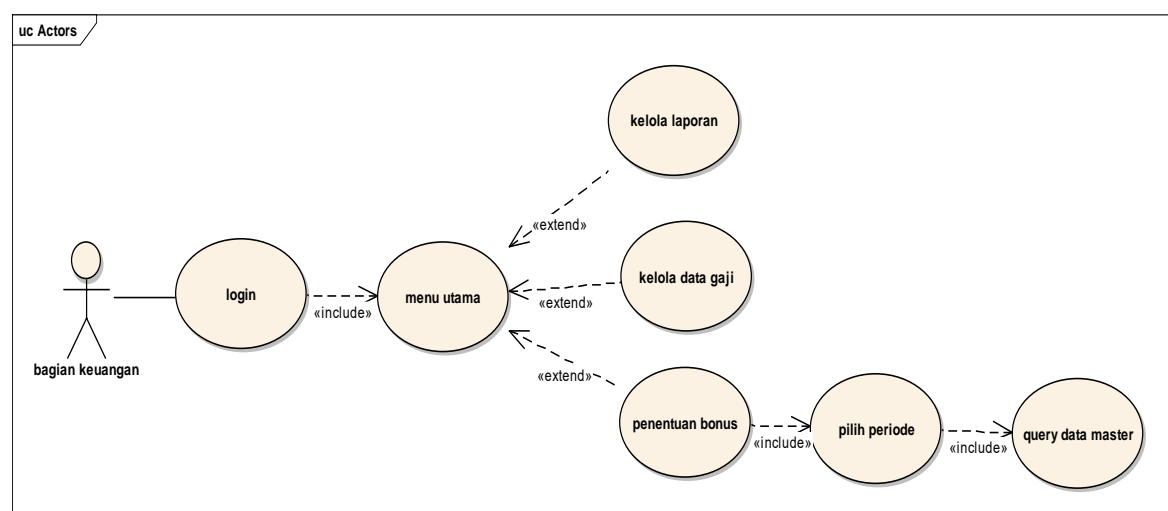

Gambar 10. Use-Case Diagram Bagian Keuangan

A. Use-Case Diagram Direktur

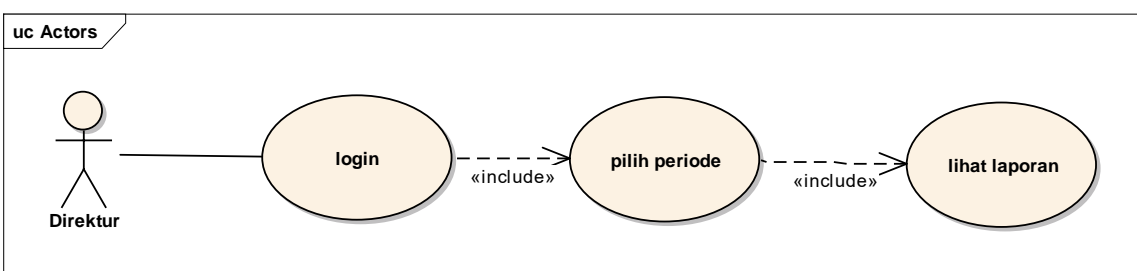

Gambar 11. Use-Case Diagram Direktur

3.3 Class Diagram

Berikut ini class diagram berdasarkan use-case diagram yang sudah dibuat sebelumnya :

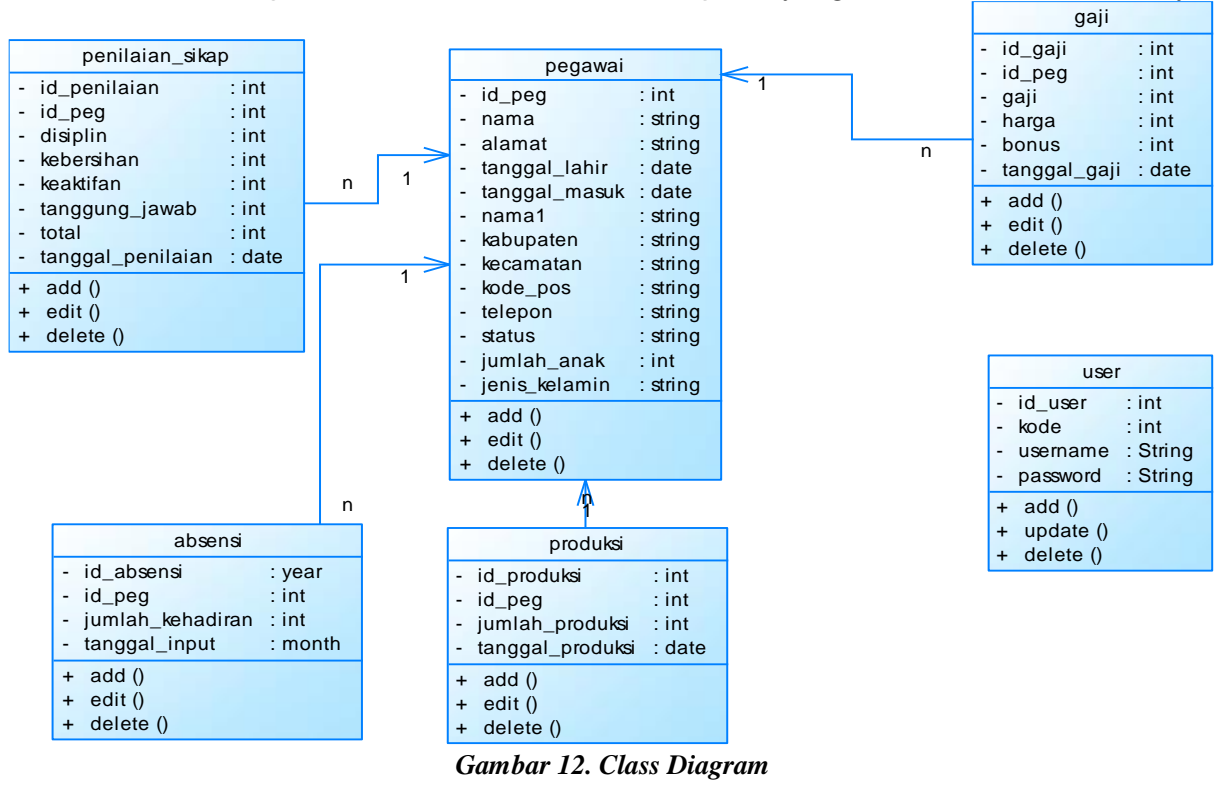




\section{Impelementasi}

\subsection{Form Login}

Form ini merupakan tampilan pertama pada aplikasi. Pada form ini Human Resource Development, Bagian Keuangan dan Direktur untuk memasukkan username dan password untuk masuk ke halaman home.

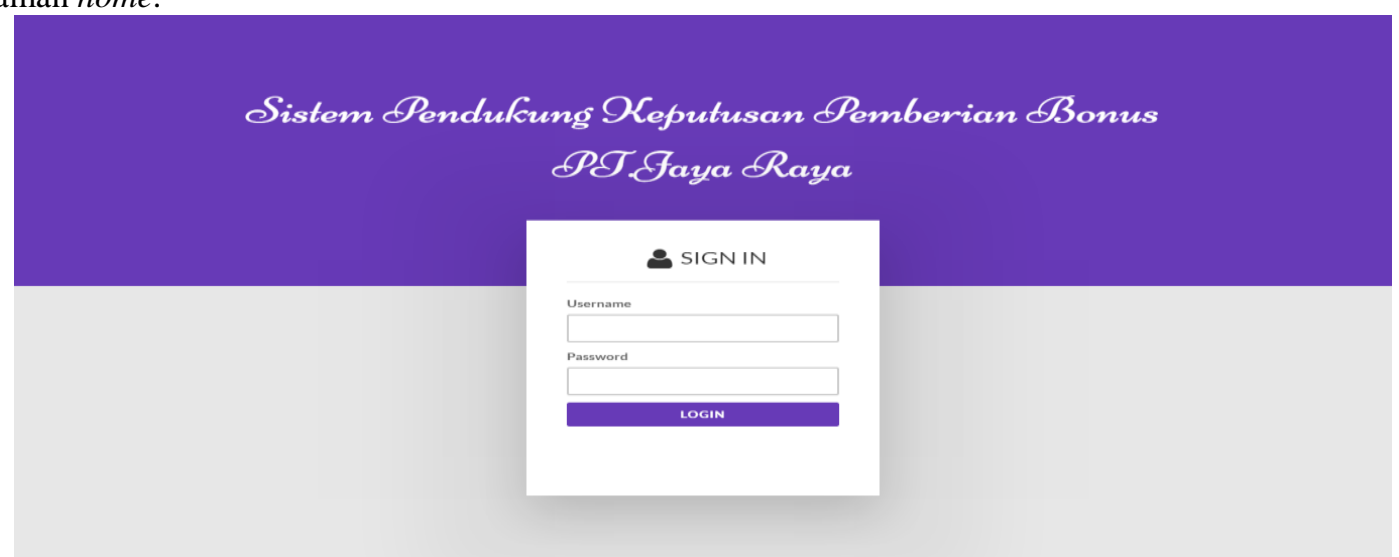

Gambar 13. Tampilan Form Login

\subsection{Implementasi Halaman Penentuan Bonus}

Pada menu penentuan bonus menampilkan hasil penentuan bonus yang telah dilakukan. Untuk dapat melihat hasil penentuan bonus sebelumnya kita perlu memilih bulan dan tahun untuk menghitung besaran bonus yang diterima.

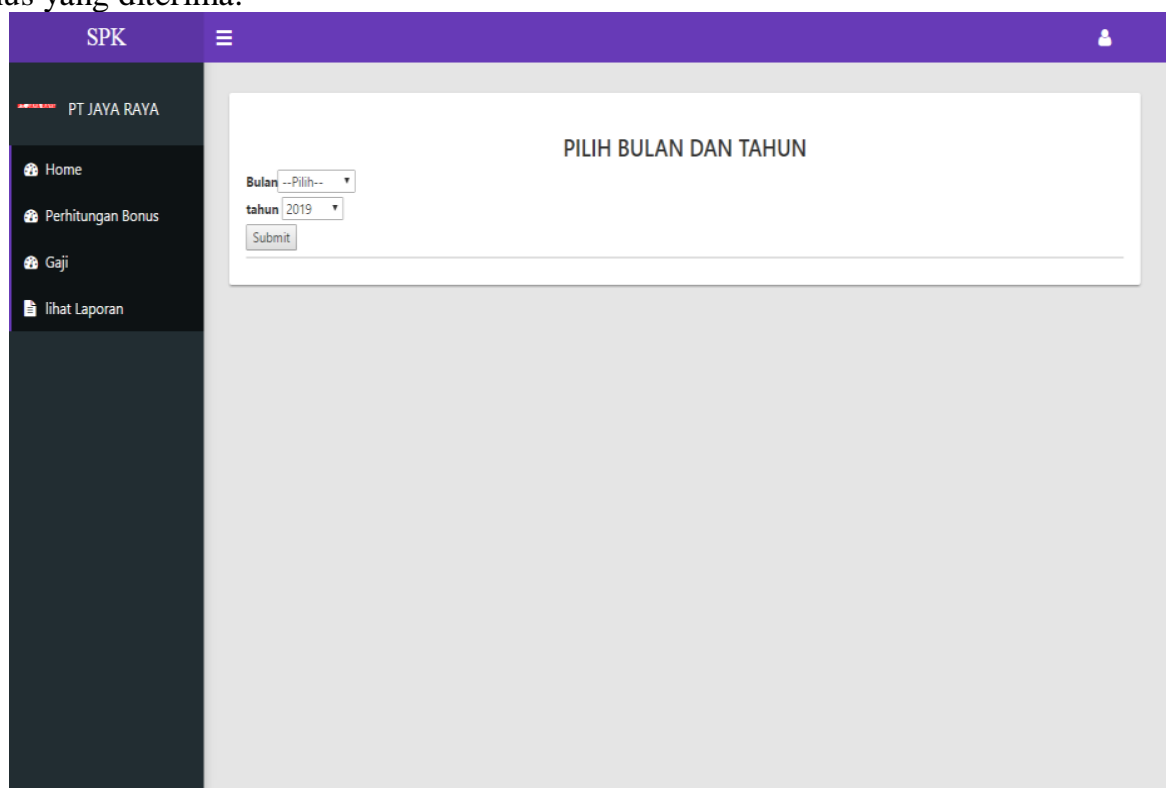

\section{Gambar 14. Tampilan Halaman Penentuan Bonus}

Saat button Submit kita pilih maka akan muncul tabel hasil query data Masa kerja, Absesnsi, Penilaian Sikap, dan Produksi berdasarkan bulan dan tahun yang telah dipilih. Pada tabel kita dapat melihat besaran bonus berdasarkan persentase yang didapat penentuan bobot setiap indikator yang ada. 


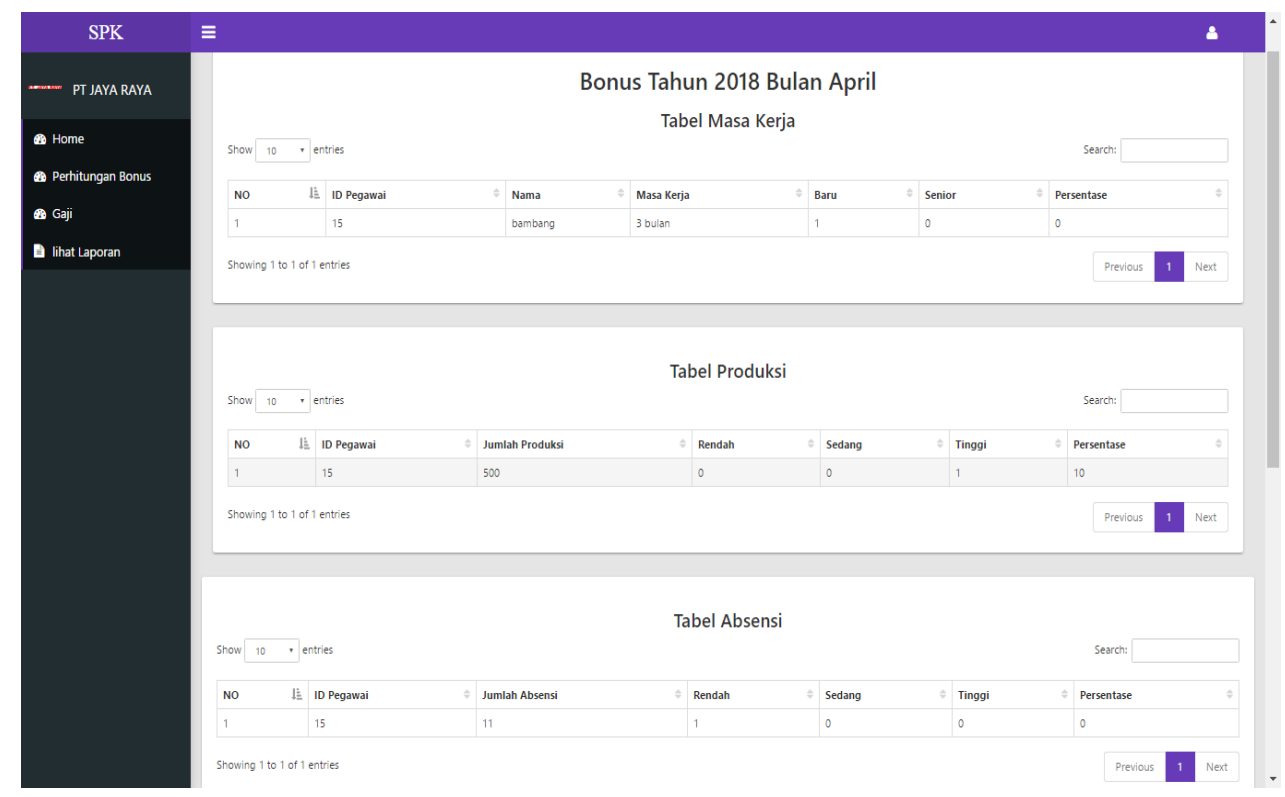

Gambar 15. Tampilan Hasil Penentuan Bonus(1)

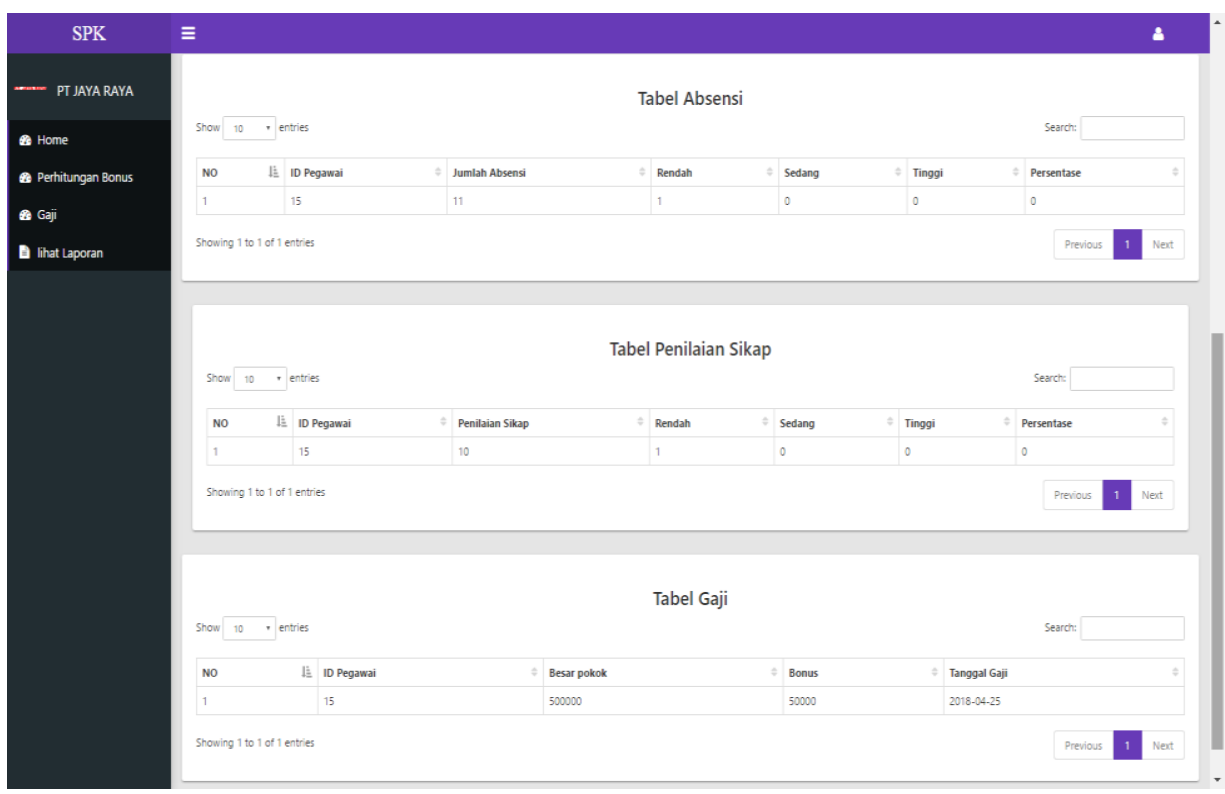

Gambar 16. Tampilan Hasil Penentuan Bonus(2)

\subsection{Implementasi Halaman Lihat Laporan}

Pada menu lihat laporan menampilkan hasil query berdasarkan data gaji berdasarkan bulan dan tahun yang telah dipilih oleh user. User dapat melakukan print berdasarkan hasil query data gaji. 


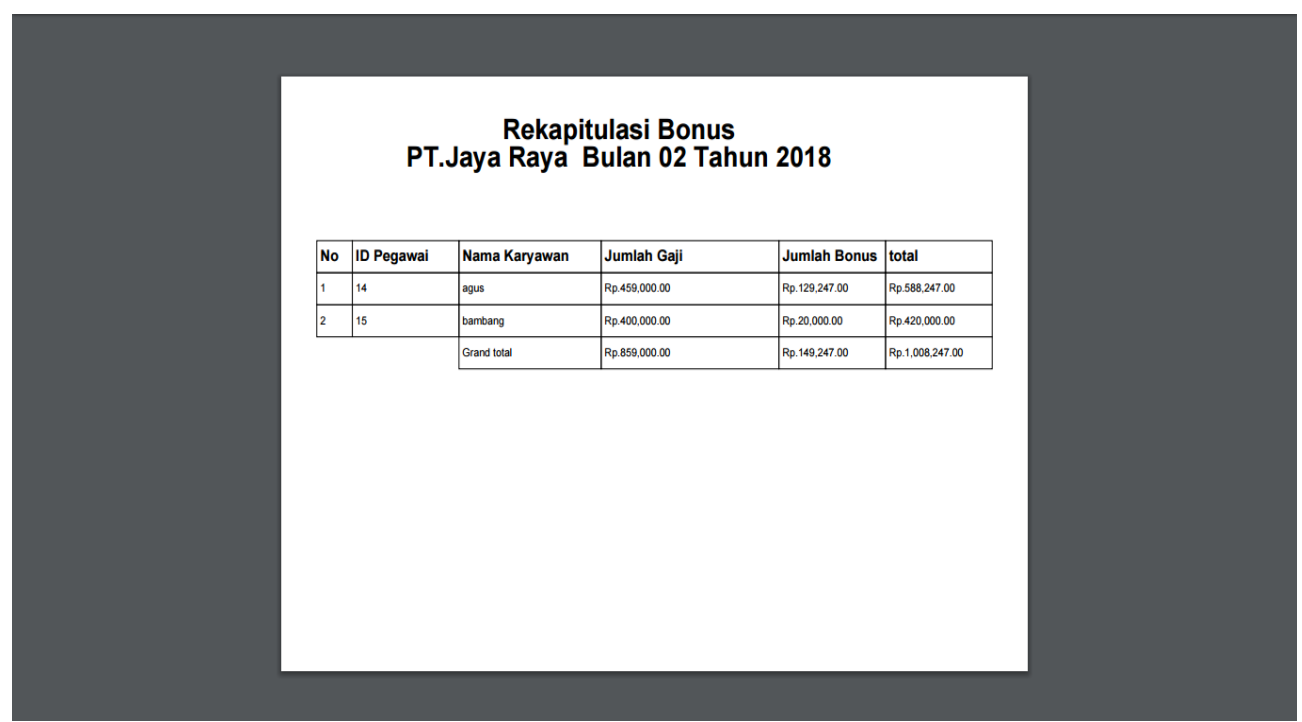

Gambar 17. Tampilan Hasil Lihat Laporan

\section{Kesimpulan dan Saran}

\subsection{Kesimpulan}

Berdasarkan masalah dan pembahasan analisis yang telah diuraikan oleh penulis diatas maka dapat diambil kesimpulan terhadap sistem pendukung keputusan pemberian bonus karyawan di PT. Jaya Raya menggunakan metode Fuzzy Logic model Tahani :

1. Sistem dapat meningkatkan objektifitas dalam menentukan besaran pemberian bonus dan mempercepat proses penentuan besaran bonus sehingga dapat mempermudah bagian keuangan.

2. Sistem dapat melakukan penentuan besaran bonus sesuai dengan kinerja karyawan sehingga top level management (Direktur) dapat menentukan keputusan dengan mudah.

3. Indikator pemberian bonus didasarkan pada empat indikator yaitu Jumlah Produksi, Kehadiran, Sikap Kerja dan Masa Kerja. dimana sikap kerja terdiri dari beberapa indikator tambahan yaitu Disiplin, Kebersihan, Keaktifan, dan Tanggung Jawab.

4. Dengan menggunakan metode Fuzzy Logic penentuan besaran bonus ditentukan berdasarkan pada pembobotan setiap indikator yaitu Produksi, Kehadiran, Sikap Kerja dan Masa Kerja.

\subsection{Saran}

Adapun saran-saran yang penulis berikan untuk pengembangan aplikasi ini selanjutnya antara lain

1. Penyajian data dalam sistem ini belum berupa grafik. Untuk itu perlu di kembangkan lagi penyajian data yang lebih beragam.

2. Perlu pengembangan yang lebih lanjut dalam proses pembuatan laporan, karena sistem ini masih sangat sederhana dalam menampilkan hasil laporan.

Perlu dipertimbangkan penggunaan metode lain dalam menentukan besaran bonus karyawan.

\section{Daftar Pustaka}

[1] Agusli. Rachman, Muhammad Iqbal Dhulhaq,Uswantu Khasanah, Sistem Pendukung Keputusan Pemberian Bonus Tahunan Karyawan Menggunakan Metode TOPSIS, Jurnal Sisfotek Global, Vol. 7, No. 2, tahun 2017

[2] Haviluddin, Memahami Penggunaan UML (Unified Modelling Language), Samarinda: Jurnal Informatika Mulawarman volume 6, 2011.

[3] Kadarsah Suryadi , Ir. Dr. \& Ali Ramdhani, Ir. M.T. Sistem Pendukung Keputusan. Rosdakarya, Bandung,2002. 
[4] Kusumadewi. Sri dan Hari Purnomo, Aplikasi Logika Fuzzy untuk Pendukung Keputusan, Yogyakarta: Graha Ilmu, 2010.

[5] Manurung. Nuriadi, Sistem Pendukung Keputusan Pemberian Bonus Karyawan Menggunakan Metode AHP, Jurnal Teknologi Informasi/JurTI, Vol. 1 No.1, tahun 2017

[6] Munawar, Pemodelan Visual dengan UML, Yogyakarta: Graha Ilmu, 2005.

[7] Peraturan Menteri Tenaga Kerja Republik Indonesia No. PER- 04/MEN/1994, tentang Tunjangan Hari Raya Keagamaan Bagi Pekerja di Perusahaan, 1994.

[8] Petrovic. Debrila, Ying Xie, Keith Burnham, Fuzzy Decission System for Demand Forecasting with a Learning Mechanism , 2006

[9] Pfleeeger, S.L. dan Atlee, J.M. Software Engineering: Theory and Practice, 3rd Edition,2006

[10] Sokibi. Petrus, Sistem Pendukung Keputusan Penilaian Kinerja Karyawan PT Harjamukti Jaya Mandiri Menggunakan Metode Simple Additive Weighting, Jurnal Teknik Informatika dan Sistem Informasi Jatisi Vol.5 No1,109-118. 2018.

[11] Surat Edaran Menteri Tenaga Kerja Republik Indonesia N0. SE- 07/MEN/1990, tentang Pengelompokan Upah dan Pendapatan Non Upah, 1990

[12] Susanto. Azhar, Sistem Informasi Manajemen, Bandung : Sinar Baru Alegesindo. 2004

[13] Turban, Efraim, et all, Decision Support and Intelligent Systems (Sistem Pendukung Keputusan dan Sistem Cerdas) edisi ketujuh jilid 1, Yogjakarta : Andi Offset,2005.

[14] Wiswakarma. Komang, 9 Langkah Menjadi Master Framework Codeigniter, Yogyakarta: Lokomedia, 2010.

[15] Yanthi. Carolina, Sistem Pendukung Keputusan Untuk Menentukan Pemberian Bonus Tahunan Menggunakan Metode Fuzzy Logic Tipe Mamdani, Jurnal Teknologi Informasi, Vol. 12, No.2, tahun 2016.

[16] Https://id.wikipedia.org/wiki/Sistem_pendukung_keputusan Diakses tanggal 23 Oktober 2:14 PM

[17] Https://id.wikipedia.org/wiki/Unified_Modeling_Language Diakses 23 Oktober 2:30 PM 